\title{
Bargaining structure and bargaining scope in New Zealand: the climate of employer opinion
}

\author{
Ian McAndrew*
}

The Labour Relations Act 1987 removed legal restrictions on the subject matter of bargaining. This article reports the results of a survey of employer opinion on current union involvement in plant decision making and on future bargaining scope. Little current union involvement is reported in either operational decisions or more basic management strategy decisions. Some limited employer support is found for the notion that bargaining scope should expand with decentralization of the bargaining structure.

The picture of industrial relations in New Zealand that emerges from a review of the Green Paper debate leading to the passage of the Labour Relations Act 1987 is of a highly regulated, highly centralized, fairly confrontational, and essentially one-dimensional labour relations system, with the operative dimension being wages. This is a model designed for equity, or more properly, equality of wage treatment, rather than productive efficiency, and it has clearly operated at a level somewhat remote from the average employer and employee.

The Labour Government and important business lobbies found the system incompatible with the perceived need for greater productive efficiency, in the face of the increased global competition to which New Zealand industry was being exposed. The result was the Labour Relations Act 1987, designed, with various degrees of explicitness, to decentralize, defuse, and expand the scope of the New Zealand labour relations system (Minister of Labour, 1986b). Subsequent calls from all quarters for further legislative, behavioural, and attitudinal change have continued to stress the themes of decentralization, defusion of confrontation, and sophistication of scope in the labour relations system. Government spokespeople have stuck fairly consistently to the themes of breaking established relativities in favour of settlements appropriate to particular industries and enterprises, decentralizing the bargaining structure, substituting cooperation for confrontation, and expanding the scope of labour relations (Minister of Labour, 1988a, 1988b, 1988c). The National Party's policy stresses the same themes, perhaps somewhat more vigorously. A change of government might be expected to accelerate the pace of labour relations change, but would be unlikely to reverse the directions.

* Department of Management, University of Otago. The author thanks Valerie Thompson for technical assistance, and Alan Geare, Alex Sibbald, Pat Walsh and anonymous Journal referees for helpful comments. 


\section{The research programme defined}

The twin focuses of the research reported in this paper are two aspects of private sector collective bargaining in New Zealand: its structure, or the level at which it occurs; and its scope, or the range of subjects negotiated. Specifically, the study sought out the attitudes toward bargaining structure and scope, and toward union and employee involvement in bargaining, of those member firms of the Otago-Southland Employers Association employing between ten and one hundred staff. The cutoff at one hundred staff reflects the conventional wisdom that the future of New Zealand industry and employment will remain firmly rooted in small and medium sized firms. The minimum staff level of ten reflects the writer's experience that enterprise bargaining in very small firms is usually not viable The intent, in short, was to select a sample of employers to whom enterprise bargaining would apply if it were widely practiced in New Zealand.

\section{The scope of bargaining in New Zealand}

The legislative history of the range of bargaining issues in New Zealand can be summarized briefly. The Industrial Relations Act of 1973 carried over the 1954 Industrial Conciliation and Arbitration Consolidated Act's scope of matters negotiable within the formal system. Industrial matters were defined as "...all matters affecting or relating to work to be done by workers, or the privileges, rights and duties of employers or workers in any industry...". This seemingly broad language was, however, reduced by a limited number of judicial interpretations to a relatively narrow scope of application (Minister of Labour, 1985a, p.18; Geare, 1983, p.193-195).

The restrictions associated with this definition were removed as one of the deregulatory elements of the 1987 legislation. The Government predicted that:

Unions and employers will be able to come to their own conclusions about the proper subjects of their negotiations, and may end up bargaining on subjects as diverse as the introduction of new technology, superannuation schemes, the provision of childcare facilities, and so on (Minister of Labour, 1986b, p.11).

\section{Production cost pressures, employee security, and scope}

The seminal work on union intrusions into managerial decision-making remains Neil Chamberlain's 1948 study of American enterprise bargaining and job control unionism. Chamberlain found the "primary rationale" of union leaders "penetrating" management decision making to be the view "that any managerial decisions or authority threatening the security of workers must be regulated" (Chamberlain, 1967, p.89).

He reported that, in the union view, security related to decisions affecting not merely wages, but also "the selection of employees for layoff, rehiring, and promotion ...assignment of employees to jobs...their transfer...the disciplining of employees...the scale and schedule of production, the introduction of labour-saving devices...<and $>$ the closing or relocation of plants" (Ibid., pp.93-94). The unions, Chamberlain noted, adopted a two-pronged approach. At the same time that they sought to control these elements of the job, American unions recognized the importance of general economic conditions and employment levels for the security of workers, and sought to influence macro-economic policies as well (Ibid., pp.95-96).

\section{The issue of concession bargaining}

Milton Derber and his colleagues, in a longitudinal study of bargaining scope in the United States in the 1950 's, found that bargaining scope expanded as a result of economic pressure for production cost reduction:

In each of the six cases where scope of union participation had increased, the establishment had been confronted by economic pressures (more severe competition or a decline in business), and management had made an effort to increase plant efficiency. In each of these cases, union participation had increased in at least one of the following items - contracting work out, number of employees on a job or machine, level of work performance, scheduling of operations, job evaluation, or job content. In practically every case, the management would have preferred not to have the union involved in the item, but felt obliged to acquiesce in such involvement (Derber, Chalmers \& Edelman, 1961, p.95).

In the late 1970s and the 1980s, concession bargaining was generated in the United States by increased product market competition for unionized firms from both foreign producers and non-union domestic firms. Robert McKersie and his colleagues have well described the strategic choices available to these firms (Kochan, McKersie \& Cappelli, 1984; Cappelli \& McKersie, 1987). Among them was the seeking of production cost cuts and productivity improvements through union concessions.

While private sector union density continues to decline in the United States, unionized plants largely remain unionized (Strauss, 1984). Clearly, however, major employers have seized the initiative in the labour relationship in unionized plants, increasingly implementing corporate human resources management policies and shop floor worker involvement policies designed to increase operational flexibility and enhance the commitment of individual workers. The demanding of concessions at the bargaining table has complemented these strategies implemented at other organizational levels (Kochan \& Piore, 1985). Management has gained wage concessions, in such forms as simplification of pay structures, pay freezes, delayed and contingent pay arrangements, and even pay cuts, together with work rule changes, dealing broadly with the assignment of work and personnel and with production standards.

Unions have responded to management concession proposals with renewed interest and some gains in benefit programs, profit sharing and other alternative compensation forms, employment and income security guarantees, and a broadened union role in both operational decisions and strategic management decisions on such matters as plant closings and relocations, technological changes, and the contracting out of work (Kassalow, 1983; Mills, 1983; Cappelli, 1984; Kochan \& Piore, 1985; Cappelli \& McKersie, 1987). While the future role of unions in unionized plants remains subject to speculation, it seems probable that it will be permanently broader in scope than has historically been the case (Cappelli \& McKersie, 1985).

In short, as Chamberlain would have predicted, recent economic pressures to cut production costs have heightened union interest in employee security, and further broadened the already broad United States bargaining agenda. Interestingly, there is some evidence that union gains in concession bargaining, in addition to union concessions, may have helped rather than hurt unionized employers in the United States, perhaps by promoting that elusive sense of "common purpose" (Becker, 1988).

\section{Implications for New Zealand}

The economic pressures of international competition are being keenly felt by New Zealand industry. These pressures have motivated the widespread call for cost reduction 
and permanent productivity improvements. An embryonic concession bargaining approach surfaced in the 1988 award negotiations, with proposals for pay simplification and work rule flexibility put on the table by both public and private sector employers in the context of no-cost or low-cost settlements. As Grills has recently noted, the continued dismantling of the welfare state will provide unions with additional incentive to add superannuation, health care, and other benefit programmes to the bargaining agenda (Grills, 1988, p.161). And finally, a seemingly permanent element of unemployment, as a relatively new feature of the New Zealand economy, has potentially sweeping implications for the bargaining agenda.

When there is no longer a job available for everyone, workers become more conscious of their rights to what is available. As the already apparent employer resistance to the wage-based redundancy payment approach stiffens, unions may well seek to establish workers relative rights to work, to retraining, to relocation, and to rehire, as well as intensifying efforts to broaden the union's role in strategic management decisions that bear on employee security.

Certainly there is ample reason to believe that Chamberlain's "primary rationale" must be at the forefront of New Zealand union thinking; the only real question has been whether the unions would turn to the bargaining table under the new freedom of legally unrestricted scope to complement their traditional approaches.

\section{The union response in New Zealand}

The published positions of the New Zealand Federation of Labour (FOL) at the time of the Green Paper review of labour relations in 1986 certainly put forth the view that unions had been constrained by legal restrictions, and would seek to broaden the bargaining agenda with the lifting of legal constraints on scope. The FOL submission called for the unfettered right to negotiate those matters at that time excluded from scope as "managerial prerogatives", declaring that "the concept of some pre-eminent 'right to manage' is inconsistent with modern industrial principles" (FOL, 1986, p.21)

Redundancy, new technology, staffing levels, workload, and methods of work were cited as areas where the unions sought to negotiate the initial decisions, rather than being limited to impact negotiations after the fact. Additionally:

On a wider range of issues, there needs to be provision for workers to have a real input into broader business decisions from which the various issues noted above arise. The broader issues are those of investment policy, rationalisation, restructuring and mergers/takeovers (p.21).

More recent pronouncements from the successor New Zealand Council of Trade Unions (NZCTU) have reiterated these views and expanded upon them. NZCTU leaders have recognized that the changed economic environment requires new structures and new approaches by unions, and that the removal of legal restrictions on scope opens up new opportunities:

What has become very clear to unions is that this is not a time for defensive eactions...(U)nions are now in the process of moving to restructure alon industry lines, reform our bargaining strategy so that it is consistent with an industry approach, and enlarging our vision to embrace a wider range of issue than has traditionally been the case (Douglas, 1989, p.3).

In terms of scope, the NZCTU argues for the implementation of industrial democracy at national, industry, enterprise, and workplace levels (Douglas, 1989; NZCTU, 1989). Its leadership is looking to be engaged by the government in on-going negotiations over a wide range of economic and social policy issues. Current discussions over a proposed compact appear to be directed towards establishing the mechanisms for such a broad union role, and one that would ideally extend beyond the life of the Labour Government (Foulkes, 1988).

In addition to the restructuring of awards to an industry basis, the unions also seek to be involved in a cooperative fashion at the industry level "to negotiate the adjustment path" for industries undergoing change (Foulkes, 1988). At the enterprise and workplace levels, the NZCTU envisions negotiations by workers and an expanded network of union delegates over a range of issues, including "organization of work...training and skills formation...new technology...health and safety...equal opportunities...business plans and feasibility studies" (NZCTU, 1989, p.16), as unions move from a restricted, defensive role to a more positive, embracing one under the freedom of legally unrestricted scope.

Concomitantly, in pursuing its vision of industrial democracy before the Government's Committee of Inquiry into Industrial Democracy, the NZCTU has called on employers to abandon "Taylorist work organization" and rigid concepts of "management prerogatives", and to develop production strategies and work organization methods consistent with worker and union input (Douglas, 1989; NZCTU, 1989). Interestingly, this is not a view of industrial democracy at enterprise level inconsistent with that of the Minister of Labour, who noted recently that, "The extension of collective bargaining to cover issues normally considered management prerogatives is a recognised approach to industrial democracy" (Minister of Labour, 1989, p.19).

In short, New Zealand unions are moving aggressively to broaden the bargaining agenda at national, industry, enterprise, and workplace levels under precisely the economic circumstances Chamberlain would have predicted, and presumably motivated by the same "primary rationale" he identified among American unions.

\section{Management prerogatives and scope}

What might be the expected response of New Zealand employers to union initiatives to broaden the scope of their bargaining relationship? Most studies would suggest resistance. Chamberlain found that American employers resisted union penetration of management decision making for a variety of stated reasons: "Management fears that union penetration ... destroy(s) unified final authority; the union ... constitutes a second center of authority, which speaks in terms of welfare rather than efficiency...; management objects to union penetration because of a lack of union responsibility...because it believes that union leadership is inadequate;...management suspects the motives behind union penetration...management fears the end result of union penetration..." (Chamberlain, 1967, p.131-137)

Beyond these reasons reported to him by American managers, Chamberlain suspected more personal motives were also at work:

The unions' program carries a threat to the personal goals of the managers - their security, recognition, and self-expression...It challenges their essentially realistic philosophy. These unstated reasons lend further support to an intent to hold the line (p.139)

Subsequent studies have supported Chamberlain's findings of general reluctance, while at the same time reinforcing the notion that employers will accept a broadening of scope in exchange for union concessions where to do so makes economic good sense (Derber, Chalmers \& Edelman, 1961; Kassalow, 1983; Mills, 1983; Cappelli, 1984).

While New Zealand employers have operated under such restrictions as blanke coverage awards and some legislatively mandated substantive and procedural provisions, they have not been restrained at the operational level by the type of comprehensive jo 
control collective bargaining contracts that have been common in the United States. Thus, a largely unchallenged history of exercising managerial prerogatives far broader han those enjoyed by their American counterparts would lead us to expect a strong hold the line philosophy regarding scope on the part of New Zealand employers.

\section{The employer organisation response}

In its submission on the Green Paper, the New Zealand Employers Federation (NZEF) ook the position that while a narrow definition of industrial matters was appropriate as the basis for scope under a system of national awards, a broader, even unlimited scope might be appropriate for a decentralized, essentially enterprise-based bargaining system (NZEF, 1986, p.31). The New Zealand Business Roundtable (NZBR) took an even less hesitant view, though its submission, too, was largely couched in enterprise bargaining terms (NZBR, 1986, p.67).

In short, employer organizations linked scope to the second dimension of bargaining under study here: the structure of bargaining, or the level at which it occurs. This view would allow a broad scope for bargaining perhaps consistent with the position adopted by the NZFOL/CTU, as bargaining restructures to the enterprise level, or close to it.

\section{New Zealand employers on bargaining structure}

Enterprise bargaining is, in fact, an oversimplification of the NZEF's position which

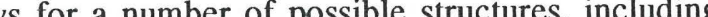
workplace company, regional, and national industrial agreements. The key, from this perspective, is a single bargaining agent representing all employees in the workplace or, upon agreement of the parties, several or many workplaces within an area or industry.

While the NZEF accommodates its broader constituency with a position somewhat softer than strict enterprise bargaining, the NZBR is decidedly less sympathetic in claiming that some employers are not quite up with the play:

There are some in employer circles as well as those on the union side who would prefer to cling to blanket coverage arrangements and avoid the need to develop prefer to cling to blanket coverage arrangenents and avoid the need wevelop positive relationships with their employees. The new Act does not put enough back (Myers, 1987, p.14)

The Green Paper review provided some indication of the pattern of employer views on bargaining structure:

Slightly over half of the submissions that looked at wage-fixing stated specifically that they supported the retention of the national award system as it is. While almost half of these were from unions, their position was supported by is. Whifie alnost hull of thividuals and organizations, as well as a small number a significant nut A number of submissions considered that the national award system should not remain the central feature or wage-fixing. Of these submissions, the majority of

(NZ Minister of Labour, 1986, p.28-29)

This would suggest that many small employers are not yet convinced of the wisdom of decentralizing the bargaining structure, but that they may yet be won over (Wood, 1988, p.169). The balance of this article seeks to begin documenting their current views on both bargaining structure and bargaining scope, and any links between the two.

\section{Design of the study}

The research data were collected by mail survey during winter, 1988. Questionnaires were mailed to all member firms of the Otago-Southland Employers Association employing between 10 and 100 staff. Two hundred and twenty-two valid, timely responses were received from an initial mailing to 476 employers, for a response rate of 46 percent. The data are presented as a single sample. Analysis by size of workforce and number of unions in the plant revealed no significant differences in responses by eithe variable. No analysis by type of industry or dominant union has been attempted, though these suggest themselves as possible directions for follow-up research.

Beyond classification data, information was requested on two areas: first, breadth and depth of union penetration and degree of workforce input in decision making under curren practice; and second, employer views on future scope at national award and enterprise agreement bargaining levels.

\section{Unions, employees, and managerial decisions}

Employers were asked to indicate how decisions in each of 12 decision areas "would be handled in your plant":

National award: This matter is specifically covered by written national award(s).

Local agreement: This matter is specifically covered by written local award(s) or agreement(s).

Established practice: This matter is handled in accordance with established practice or custom at the plant.

Negotiation-union: This matter is resolved by formal negotiations with the union(s) when the matter arises.

Discussion-union: This matter is resolved by informal discussions with the union(s) when the matter arises.

Discussion-workforce: This matter is resolved by discussion with the workforce or its representative, but without union involvement, when the matter arises.

Discussion-employee: This matter is resolved by informal discussion with just the employee(s) affected when the matter arises.

Management decision: This matter is determined solely by management.

It was recognized that "the categories may not cover every situation", and that the option chosen "may be different depending on the union involved". In such cases, employers were asked to choose "only the one option that most accurately or most often would be correct".

The twelve decision areas used throughout the study were modelled loosely on the Derber et al. research cited earlier, but modified to ensure a spread across behavioral rules, operational decisions, and basic managerial strategy decisions. They were as follows:

(1) A decision to change work starting or finishing times. [Work schedule].

(2) A decision to introduce or modify rules defining what constitutes acceptable conduct at the workplace. [Rules of conduct].

(3) A decision regarding whether a particular job or machine is safe. [Job/mach safety].

(4) A decision regarding which employee to promote to a non-supervisory position. 
[Non-supv promotn].

(5) A decision regarding which employees will work required or available overtime. [Overtime assignmt].

(6) A decision regarding the number of employees to work on a new job or machine. [\#Emplee/new job].

(7) A decision regarding which tasks to assign to which employees. [Task

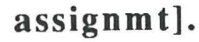

(8) A decision regarding which employees are to be made redundant in the event redundancies become necessary. [Redundnt emplyees].

(9) A decision to contract out to another firm work previously done by employees. [Contract out work].

(10) A decision to introduce new technology or machinery. [New mach/technol].

(11) A decision to close or relocate the plant. [Plant reloc/clos].

(12) A decision that redundancies have become necessary. [Redundcy necessry].

The reported extent of union and workforce input on these decisions is presented in Table 1.

Table 1: Employers' report on current decision making practices $(n=222)$

\begin{tabular}{lcccccccc}
\hline & $\begin{array}{l}\text { National } \\
\text { award }\end{array}$ & $\begin{array}{l}\text { Local } \\
\text { agrmt }\end{array}$ & $\begin{array}{l}\text { Estab } \\
\text { pract }\end{array}$ & $\begin{array}{l}\text { Negot } \\
\text { union }\end{array}$ & $\begin{array}{l}\text { Discuss } \\
\text { union }\end{array}$ & $\begin{array}{l}\text { Discuss } \\
\text { wrkfre }\end{array}$ & $\begin{array}{l}\text { Discuss } \\
\text { emplyee }\end{array}$ & $\begin{array}{l}\text { Manag } \\
\text { decis }\end{array}$ \\
\hline $\begin{array}{l}\text { Work } \\
\text { schedule }\end{array}$ & $1.4 \%$ & $1.4 \%$ & $0.9 \%$ & $3.6 \%$ & $4.5 \%$ & $49.1 \%$ & $14.0 \%$ & $25.2 \%$ \\
$\begin{array}{l}\text { Rules of } \\
\text { conduct }\end{array}$ & $1.4 \%$ & $1.8 \%$ & $2.3 \%$ & $3.2 \%$ & $5.4 \%$ & $39.6 \%$ & $5.9 \%$ & $40.5 \%$ \\
$\begin{array}{l}\text { Job/mach } \\
\text { safety }\end{array}$ & $1.4 \%$ & $0.5 \%$ & $7.6 \%$ & $1.9 \%$ & $5.2 \%$ & $52.4 \%$ & $18.6 \%$ & $12.4 \%$ \\
$\begin{array}{l}\text { Non-supv } \\
\text { promotn }\end{array}$ & $0.9 \%$ & $0.5 \%$ & $1.8 \%$ & $0.0 \%$ & $0.5 \%$ & $3.2 \%$ & $17.7 \%$ & $75.5 \%$ \\
$\begin{array}{l}\text { Overtime } \\
\text { assignmt }\end{array}$ & $0.0 \%$ & $1.4 \%$ & $7.7 \%$ & $0.0 \%$ & $0.5 \%$ & $26.2 \%$ & $24.0 \%$ & $40.3 \%$ \\
$\begin{array}{l}\text { \#Emplyee } \\
\text { /new job }\end{array}$ & $0.0 \%$ & $0.5 \%$ & $3.3 \%$ & $2.8 \%$ & $2.4 \%$ & $21.3 \%$ & $9.5 \%$ & $60.2 \%$ \\
$\begin{array}{l}\text { Task } \\
\text { assignmt }\end{array}$ & $0.9 \%$ & $0.0 \%$ & $5.5 \%$ & $0.5 \%$ & $0.5 \%$ & $15.0 \%$ & $13.2 \%$ & $64.5 \%$ \\
$\begin{array}{l}\text { Redundant } \\
\text { emplyees }\end{array}$ & $0.9 \%$ & $1.4 \%$ & $0.5 \%$ & $11.2 \%$ & $11.2 \%$ & $12.1 \%$ & $4.7 \%$ & $57.9 \%$ \\
$\begin{array}{l}\text { Contract } \\
\text { out work }\end{array}$ & $0.0 \%$ & $0.0 \%$ & $0.9 \%$ & $0.9 \%$ & $8.2 \%$ & $14.9 \%$ & $4.6 \%$ & $70.3 \%$ \\
$\begin{array}{l}\text { New mach } \\
\text { /technol }\end{array}$ & $0.0 \%$ & $0.9 \%$ & $0.0 \%$ & $1.8 \%$ & $5.0 \%$ & $19.2 \%$ & $5.5 \%$ & $67.6 \%$ \\
\hline
\end{tabular}

Table 1 (cont.): Employers' report on current decision making practices $(n=222)$ $\begin{array}{lllllll}\text { National Local } & \text { Estab } & \text { Negot } & \text { Discuss } & \text { Discuss } & \text { Discuss } & \text { Manag } \\ \text { award } & \text { agrmt } & \text { pract union } & \text { union } & \text { wrkfrce } & \text { emplyee } & \text { decis }\end{array}$

agrmt pract union

union

wrkfrce

emplyee decis

$\begin{array}{lcccccccc}\begin{array}{l}\text { Plant re } \\ \text { loc/clos }\end{array} & 0.0 \% & 0 \% & 1.0 \% & 6.9 \% & 3.4 \% & 12.7 \% & 1.5 \% & 73.5 \% \\ \begin{array}{l}\text { Redundcy } \\ \text { necessry }\end{array} & 1.4 \% & 1.4 \% & 0.5 \% & 2.8 \% & 4.2 \% & 6.9 \% & 1.4 \% & 81.5 \%\end{array}$

The eight input options can be collapsed into three broader categories for a consolidated view of the breadth of union penetration. Thus, in Table 2 , Union Involvement incorporates the National Award, Local Agreement, Established Practice, NegotiationUnion, and Discussion-Union options. Employee Consultation incorporates Discussion-Workforce and Discussion-Employee, while Management Decision stands alone.

Table 2: Employer's report on current union and employee involvement in decision making ( $n=222$ )

\begin{tabular}{lccc}
\hline & $\begin{array}{l}\text { Union } \\
\text { involvement }\end{array}$ & $\begin{array}{l}\text { Employee } \\
\text { consultation }\end{array}$ & $\begin{array}{l}\text { Management } \\
\text { decision }\end{array}$ \\
\hline $\begin{array}{l}\text { Work } \\
\text { schedule }\end{array}$ & $11.7 \%$ & $63.1 \%$ & $25.2 \%$ \\
$\begin{array}{l}\text { Rules of } \\
\text { conduct }\end{array}$ & $14.0 \%$ & $45.5 \%$ & $40.5 \%$ \\
$\begin{array}{l}\text { Job/mach } \\
\text { safety }\end{array}$ & $16.7 \%$ & $71.0 \%$ & $12.4 \%$ \\
$\begin{array}{l}\text { Non-supv } \\
\text { promotn }\end{array}$ & $3.6 \%$ & $20.9 \%$ & $75.5 \%$ \\
$\begin{array}{l}\text { Overtime } \\
\text { assignmt }\end{array}$ & $9.5 \%$ & $50.2 \%$ & $40.3 \%$ \\
$\begin{array}{l}\text { \#Emplyee } \\
\text { /new job }\end{array}$ & $9.0 \%$ & $30.8 \%$ & $60.2 \%$ \\
$\begin{array}{l}\text { Task } \\
\text { assignmt }\end{array}$ & $7.3 \%$ & $28.2 \%$ & $64.5 \%$ \\
$\begin{array}{l}\text { Redundnt } \\
\text { emplyees }\end{array}$ & $25.2 \%$ & $16.8 \%$ & $57.9 \%$ \\
$\begin{array}{l}\text { Contract } \\
\text { out work }\end{array}$ & $10.3 \%$ & $19.5 \%$ & $70.3 \%$ \\
$\begin{array}{l}\text { New mach } \\
\text { /technol }\end{array}$ & $7.8 \%$ & $24.7 \%$ & \\
& & & \\
\hline
\end{tabular}


Table 2 (cont.): Employer's report on current union and employee involvement in decision making ( $n=222)$

$$
\text { Union }
$$

involvemen

Employee
consultation

\section{Plant re}

loc/clos

\section{Redundcy}

necessry

$10.2 \%$

$8.3 \%$

$81.5 \%$

\section{Future scope: employer opinions}

Employers were asked, first, to indicate those of the twelve decision areas for which ey "would approve generally applicable rules being negotiated into national or multidistrict awards". Secondly, employers were asked to indicate those of the twelve decision areas "for which you would be prepared to negotiate privately with the union(s) (either ares to benerally applied in your plant, if directly or the separate a should (the be made solely by management (and therefore not subject to negotiations with the union(s), either over general rules or individual cases, at any level". The results for all three questions are presented in Table 3.

Table 3: Employer willingness to negotiate decisions at national award and plant agreement levels $(n=222)$

\begin{tabular}{|c|c|c|c|}
\hline & $\begin{array}{l}\text { Approve } \\
\text { national } \\
\text { award } \\
\text { negotiation }\end{array}$ & $\begin{array}{l}\text { Approve } \\
\text { plant } \\
\text { agreement } \\
\text { negotiation }\end{array}$ & $\begin{array}{l}\text { Solely } \\
\text { management } \\
\text { decision }\end{array}$ \\
\hline $\begin{array}{l}\text { Work } \\
\text { schedule }\end{array}$ & $19.8 \%$ & $36.9 \%$ & $48.6 \%$ \\
\hline $\begin{array}{l}\text { Rules of } \\
\text { conduct }\end{array}$ & $45.9 \%$ & $58.1 \%$ & $39.2 \%$ \\
\hline $\begin{array}{l}\text { Job/mach } \\
\text { safety }\end{array}$ & $65.3 \%$ & $63.5 \%$ & $21.6 \%$ \\
\hline $\begin{array}{l}\text { Non-supv } \\
\text { promotn }\end{array}$ & $0.0 \%$ & $6.3 \%$ & $87.8 \%$ \\
\hline $\begin{array}{l}\text { Overtime } \\
\text { assignmt }\end{array}$ & $1.4 \%$ & $17.1 \%$ & $72.1 \%$ \\
\hline $\begin{array}{l}\text { \#Emplyee } \\
\text { /new job }\end{array}$ & $5.0 \%$ & $17.1 \%$ & $69.8 \%$ \\
\hline $\begin{array}{l}\text { Task } \\
\text { assignmt }\end{array}$ & $2.3 \%$ & $5.0 \%$ & $85.6 \%$ \\
\hline
\end{tabular}

Table 3 (cont.): Employer willingness to negotiate decisions at national award and plant agreement levels $(n=222)$

\begin{tabular}{lcll} 
& $\begin{array}{l}\text { Approve } \\
\text { national } \\
\text { award } \\
\text { negotiation }\end{array}$ & $\begin{array}{l}\text { Approve } \\
\text { plant } \\
\text { agreement } \\
\text { negotiation }\end{array}$ & $\begin{array}{l}\text { Solely } \\
\text { managem } \\
\text { decision }\end{array}$ \\
\hline $\begin{array}{l}\text { Redundnt } \\
\text { emplyees }\end{array}$ & $12.6 \%$ & $25.7 \%$ & $68.0 \%$ \\
$\begin{array}{l}\text { Contract } \\
\text { out work }\end{array}$ & $3.2 \%$ & $7.2 \%$ & $81.1 \%$ \\
$\begin{array}{l}\text { New mach } \\
\text { technol }\end{array}$ & $0.5 \%$ & $3.6 \%$ & $88.7 \%$ \\
$\begin{array}{l}\text { Plant re } \\
\text { loc/clos }\end{array}$ & $3.2 \%$ & $5.0 \%$ & $86.0 \%$ \\
$\begin{array}{l}\text { Redundcy } \\
\text { necessry }\end{array}$ & $1.4 \%$ & $5.0 \%$ & \\
& & & $86.5 \%$
\end{tabular}

\section{Current union involvement in managerial decisions}

It is clear from Tables 1 and 2 that, in the firms surveyed, union input in the decision areas tested is not extensive. Indeed, three-quarters of the employers in the sample report no union involvement in any of the decision areas tested. Where union involvement is reported, the top end of the scale shows 25.2 percent of employers indicating that unions are or would be involved in the selection of employees to be made redundant. Interestingly, this is a decision area where the affected employees look perhaps least kindly on the decision-makers. At the other end of the scale, union involvement in the selection of employees for promotion is reported by only 3.6 percent of employers in the sample. At the midpoint, union involvement is reported by more than one in 10 employers for the safety issue (16.7 percent), rules of conduct (14.0 percent), plant relocation or closure (12.3 percent), starting and finishing times (11.7 percent), contracting out of work (10.3 percent), and the decision as to whether redundancies are necessary (10.2 percent).

The depth of union involvement is as limited as its breadth. Consolidating the National Award, Local Agreement and Negotiation-Union decision making options, negotiation was reported by only 13.6 percent of employers on the redundancy selection issue, in contrast to the 25.2 percent overall level of union involvement on that issue. The contrast between involvement and negotiation on the other issues was equally apparent: 3.8 percent negotiation on safety issues versus 16.7 percent involvement, and 6.4 percent negotiation on rules of conduct versus 14.0 percent involvement. The pattern continued throughout all of the issues, more pronounced on some than on others.

The 12 decision areas can be grouped into three categories: Plant Rules incorporating start and finish times, rules of conduct, and safety; Assignment of Work and Personnel incorporating promotion, overtime assignment, determining the number of employees for a new job, task assignment, and the selection of redundant employees: and Asset Management incorporating contracting out of work, new technology, closure or relocation, and the decision that redundancies are necessary. Using these categories and simple averaging, 14.1 percent of employers reported union involvement in the making of plant rules, 10.9 percent reported union involvement in assignment 
decisions, and 10.2 percent reported a role for unions in asset management decisions.

\section{Employer willingness to negotiate}

Employers are, in varying degrees depending on the issue involved and the level at hich bargaining occurs, prepared to negotiate beyond the demands presently being placed upon them. This is most concisely shown in Table 4, using the consolidated union negotiation column alongside the more encompassing union involvement column.

Table 4: Employer willingness to negotiate decision categories at national award and plant agreement levels $(n=222)$

\begin{tabular}{|c|c|c|c|c|}
\hline $\begin{array}{l}\text { Decision } \\
\text { category }\end{array}$ & $\begin{array}{l}\text { Current } \\
\text { union } \\
\text { involvement }\end{array}$ & $\begin{array}{l}\text { Current } \\
\text { union } \\
\text { negotiation }\end{array}$ & $\begin{array}{l}\text { Approve } \\
\text { national } \\
\text { award } \\
\text { negotiation }\end{array}$ & $\begin{array}{l}\text { Approve } \\
\text { plant } \\
\text { agreement } \\
\text { negotiation }\end{array}$ \\
\hline $\begin{array}{l}\text { Plant } \\
\text { rules }\end{array}$ & $14.1 \%$ & $5.5 \%$ & $43.7 \%$ & $52.8 \%$ \\
\hline $\begin{array}{l}\text { Work/pers } \\
\text { assignment }\end{array}$ & $10.9 \%$ & $4.2 \%$ & $4.3 \%$ & $14.2 \%$ \\
\hline $\begin{array}{l}\text { Asset } \\
\text { management }\end{array}$ & $10.2 \%$ & $4.3 \%$ & $2.1 \%$ & $5.2 \%$ \\
\hline
\end{tabular}

Obviously, there is room for significant expansion of negotiations over plant rules in Obviously, there is room for significant expansion of negotiations over plant rules in the context of either national awards or enterprise agreements. This is true on all three of the plant rules tested - start and finish times, rules of conduct, and safety - but it is most pronounced on the safety issue. Over 60 percent of employers in the sample are prepared to have safety issues negotiated at either level. At the other extreme, there appears to be fairly unanimous resistance on the part of employers to negotiations at any level over any fairly unanimous resistance on the decisions to of those decisions categorized hew technology, to close or relocate the plant, and to lay contract out work, to introduce new technology, to close or relocate the plant, and to lay
off staff. These types of decisions are, of course, not only those that evoke most strongly in employers the personal motivations of which Chamberlain wrote, they are also those that impact most basically on the viability of an enterprise and, ultimately, the job and that impact most basically on the vas income security of its employees. Thus, it is in the misonel - where initial skirmishes operational decisions over the collaborative relationships are likely to be initiated.

to be initiated.
Though the numbers are fairly small, employer responses in the sample indicate that there is some room to expand negotiations over the assignment of personnel, but only in plant level bargaining, not at the national award level. This is especially true on the issues of overtime assignment, determining the number of employees to work on a new issues of overtime assignment, determining ass and redundancy. Promotions and task job or machine, all employers, beyond scope at either level of bargaining.

, for almost all employers, beyond scope at either traditional issues of "management

Work and personnel assignment decisions are traditional issues of "management prerogative". Although less critical to business viability than asset management decisions, they nonetheless affect efficiency, employee security, and the job and income rights of employees relative to one another. There is at least a weak signal from employers that some of these operational issues may be negotiable at the enterprise leve but not under the current national award structure.

\section{Bargaining scope and bargaining structure}

The broader evidence on employer willingness to negotiate at enterprise versus nationa level is somewhat mixed. On each issue other than safety, more employers expressed willingness to negotiate at plant level than to have the issue negotiated at national award level. On 5 issues, the margins were sufficient and the numbers large enough to make the results noteworthy. Nearly twice as many employers were prepared to negotiate work hours locally as were willing to have hours set by national award. Twenty six percent more were prepared to negotiate rules of conduct locally, although large numbers of employers were prepared to negotiate this issue at either level.

About one in 6 employers were willing to negotiate rules governing overtime assignment at plant level; virtually none were willing to have such rules negotiated at the national level. Again, about one in 6 employers were prepared to negotiate locally over the number of employees to be assigned to a new job or machine, whereas few were prepared to have this matter dealt with at national level. And twice as many employers were prepared to negotiate rules for selection of employees to be made redundant at the plant level as at the national level.

On half of the issues, while more employers were willing to negotiate locally than nationally, the numbers who were prepared to negotiate at either level were so small as to make the margins meaningless. A strong sense of management prerogative overwhelmed any local versus national comparison on the issues of promotion and task assignment, as well as on all four asset management issues.

Finally, on the safety issue, about equal numbers - close to two out of three - were prepared to either negotiate at plant level or have the matter handled in national awards.

\section{Conclusions}

In the firms studied, unions are not at present greatly involved in either the operational decisions or more basic managerial strategy decisions on which input was demanded in the FOL's Green Paper submission. To the extent that unions are involved, that involvement appears, for the most part, to be at a softer level than the actual negotiation envisioned for the enterprise level in the NZCTU's concept of industrial democracy.

The carrot of broader scope, associated in the official positions of employer groups with decentralization of the bargaining structure, finds limited support in the views of these employers. About half of the employers surveyed are prepared to negotiate plant rules at either national or local level. Virtually none are presently prepared to negotiate asset management decisions at either level. More, but still relatively few, are inclined to negotiate some operational work and personnel assignment issues at plant level than at national award level.

In assessing expressed employer willingness to negotiate at enterprise level, it is appropriate to keep in mind that both enterprise bargaining and the negotiation at any level over most of these issues represent sizable departures for the average employer from the rather remote and one-dimensional labour relations system of their experience to date. Advocates of enterprise level bargaining under whatever name might conclude that the willingness to negotiate enterprise agreements, particularly on work and personnel assignment issues, is in itself encouraging, regardless of the size of the numbers. Clearly, there is a need for more in-depth follow-up research into employer attitudes. To the extent that South Islanders are different, or perceived to be, examination of a more national sample may be appropriate.

The suggestion of a link between structure and scope needs further testing. Differences by industry and principal union warrant examination as, in time, will the influences of expanded composite bargaining and union restructuring. To the extent that even a small 
number of these relatively small employers have expressed a willingness to negotiate quite comprehensive local agreements, it would be of interest to know why, to know how the envision an enterprise bargaining system operating, and to know what they see as the role of the union in the enterprise.

It is clear from the data that the concept of managerial prerogative remains alive and well with many New Zealand employers. Whether this is a doctrinaire or more practical view, or its motivation relative to Chamberlain's findings or the NZCTU's urgings, is probably impossible to gauge from a postal survey. It is certainly an issue worth further research.

While it is not the present subject of this research, it goes without saying that the views of union operatives, and shop floor representatives to the extent that they are in place, on both bargaining scope and bargaining structure, are equally important and worthy of empirical research.

One interesting but rather fuzzy by-product of the research is the quite widely reported practice of employee consultation as suggested in Tables 1 and 2. On almost all of the 12 decision areas tested, input from the workforce or individual employees was more widely reported than union input. No claims are made here for that result. Employee or workforce 'discussion' can mean many things, and no effort was made to test the nature of these reported discussions. Certainly, however, given employer interest in employee cooperation, and union and government interest in industrial democracy, current practice and employer attitudes in this area deserve empirical study. This is perhaps particularly so as it relates to the future role of unions in the enterprise under deregulated scope and a decentralizing bargaining structure. There may not be room in the plant for all of these new concepts.

\section{References}

Becker, Brian E (1988) Concession bargaining: the meaning of union gains Academy of management journal 31(2):377-387.

Cappelli, Peter (1984) Union improvements under concession bargaining Proceedings of the thirty-sixth annual meeting: 297-304, Madison: Industrial Relations Research Association.

Cappelli, Peter \& McKersie, Robert B (1985) Labor and the crisis in collective bargaining. In Thomas A Kochan (ed.) Challenges and choices facing American labor Cambridge, Mass., The MIT Press.

Cappelli, Peter \& McKersie, Robert B (1987) Management strategy and the redesign of workrules Journal of management studies 24(5):441-462.

Chamberlain, Neil W (1967) The union challenge to management control Archon Books.

Derber, Milton, Chalmers, W E \& Edelman, Milton T (1961) Union participation in plant decision-making Industrial and labor relations review 15(3):83-101.

Douglas, Ken (1989) Industrial democracy: trade union perspective Address to seminars on industrial democracy organised by the Industrial Relations Centre, Victoria University (May, 1989). Unpublished.

Foulkes, Angela (1988) Industrial relations and the National Party Address to a National Party Seminar on Industrial Relations (19 November, 1988). Unpublished. Geare, Alan J (1983) The system of industrial relations in New Zealand Wellington,
Butterworths.

Grills, Walter (1988) Labour market flexibility: wage relativities under the Labour Relations Act 1987 New Zealand journal of industrial relations 13(2):157-166.

Kassalow, Everett M, (1983) Concession bargaining - something old, but also something quite new Proceedings of the thirty-fifth annual meeting: 372-382, Madison, Industrial Relations Research Association.

Kochan, Thomas A, McKersie, Robert B \& Cappelli, Peter (1984) Strategic choice and industrial relations theory Industrial Relations 23(1):16-39.

Kochan, Thomas A \& Piore, Michael J (1985) US industrial relations in transition. In Thomas A Kochan (ed.) Challenges and choices facing American labor Cambridge, Mass., The MIT Press.

Mills, D Quinn (1983) When employees make concessions Harvard business review 83(3):103-113.

Minister of Labour (1985a) Industrial relations: a framework for review: volume on Wellington, Government Printer.

Minister of Labour (1985b) Industrial relations: a framework for review: volume two Wellington, Government Printer.

Minister of Labour (1986a) Industrial relations: a framework for review: summary of submissions Wellington, Government Printer.

Minister of Labour (1986b) Government policy statement on labour relation Wellington, Government Printer.

Minister of Labour (1988a) Address to the New Zealand Institute of Management (6 July, 1988). Unpublished.

Minister of Labour (1988b) Address to the New Zealand Electrical, Electronic and Related Trades Union (13 September, 1988). Unpublished.

Minister of Labour (1988c) Address to the Courtenay Place Rotary Club (4 November, 1988). Unpublished.

Minister of Labour (1989) Address to seminars on industrial democracy organised by the Industrial Relations Centre, Victoria University of Wellington (May, 1989). Unpublished.

Myers, Douglas (1987) Labour market reform: getting it right. In Labour markets \& employment Wellington, New Zealand Business Roundtable (1988).

NZ Business Roundtable (1986) New Zealand labour market reform: a submission in response to the green paper Wellington, NZBR.

NZ Council of Trade Unions (1989) Submission to the industrial democracy committee of inquiry Wellington, NZCTU. 


\section{Ian McAndrew}

NZ Employers Federation (1986) The industrial relations green paper: an employer perspective Wellington, NZEF.

NZ Federation of Labour (1986) Looking ahead: NZFOL viewpoint on industrial relations reform Wellington, NZFOL.

Strauss, George (1984) Industrial relations: time for change Industrial relations 23(1):115.

Wood, Greg (1988) The Labour Relations Act and changes to the structure of bargaining New Zealand journal of industrial relations 13(2):167-177. 